\title{
Student Perceptions of the Image of Medan State University through Instagram Social Media Account @unimedofficial
}

\author{
$1^{\text {st }}$ Nelly Armayanti ${ }^{1}, 2^{\text {nd }}$ Dodi Pramana ${ }^{2}$ \\ \{nellyarmayanti@unimed.ac.id $\left.{ }^{1}\right\}$ \\ Jl. William Iskandar Pasar V, Medan Estate, Medan ${ }^{1,2}$
}

\begin{abstract}
Currently, social media, one of which is Instagram, is a communication instrument that widely used at all levels of society, not only to disseminate information, but also to build an image. In this regard, Medan State University (UNIMED) has an Instagram social media account, @unimedofficial, as a means to report all its activities to the public. The hope of creating this account, of course, is feedback or public response to what UNIMED has been doing so far. This is what motivated us to conduct a research entitled Student Perceptions of the Image of Medan State University through Instagram Social Media Account@unimedofficial. The purpose of this research is to know students' perceptions of UNIMED. This research is a qualitative descriptive research. The population in this research were students of the Office Administration Education Study Program, while the sample or informants in this research amounted to 80, which were taken from the seventh semester student group. The data needed for this research were collected through interviews and documentation studies. The data obtained in this research will be processed based on the Miles and Huberman Interactive Analysis Model. With this analysis model, the data obtained will be recorded in descriptive notes and reflective notes. The recorded data will be reduced to separate the relevant and irrelevant. From the results of the reduction, the available data will be concluded and then presented in written form.This research was conducted in the UNIMED Office Administration Education Study Program, and was carried out from May to December 2021.
\end{abstract}

Keywords: Social media, instagram, @unimedofficial.

\section{Introduction}

Currently the phenomenon that occurs in the world community is the challenge of globalization. Where the future of conventional media began to be questioned. Because media experts say that conventional media is almost dead nowadays. However, the fate of conventional media seems to still exist in line with the era of media digitalization. The existence of this globalization also has an impact on progress in the mass media where along with the times the ease of accessing information about the world has become commonplace for today's society. The era of media digitization that spreads globally has indeed put a big change in the future of conventional media, in the era of the Industrial Revolution 4.0 which changed the face of mass media, conventional media will still exist and make changes and change. In conventional media and digital media today go hand in hand because of the many conventional media that change the display into digital form [1]. 
Internet users in Indonesia in early 2021 reached 202.6 million people. This number increased by 15.5 percent or 27 million people when compared to last January 2020. The total population of Indonesia itself is currently 274.9 million people, this means that internet penetration in Indonesia in early 2021 will reach 73.7 percent. This begins in a recent report released by content management service HootSuite, and social media marketing agency We Are Social in a report titled "Digital 2021" [2].

Looking at the development of internet users in Indonesia, it is emphasized that Indonesian people communicate more often through the internet, the internet makes it easier to communicate and interact without limits, with this convenience people interact using the internet so that social media sites are formed. The following is the definition of social media according to experts in the book Nasrullah, R. [3], According to Mandibergh, social media is what facilitates collaboration between users who produce content (user-generated content).

One of the social media that is currently in demand by the Indonesian people is Instagram, the users are also very diverse, from children to parents. From students to business people. Social media that focuses on various photo and video platforms whose popularity has skyrocketed to the point of being able to compete with other social media. Instagram users alone in Indonesia in 2020 reached 63 million people when presented with users based on female gender consisting of $50.8 \%$, and users based on male sex amounting to $49.2 \%$. (Source: Hootsuite 2020)

Instagram is very good for communication of institutional or organizational policies, in this case Medan State University is a government institution in the field of higher education management in Indonesia. The public relations task of Medan State University is to ensure that negative perceptions from various groups, especially students towards Medan State University, can be managed properly through the presentation of data and facts on Instagram, delivery of academic information flows, policies, and other activities. Instagram is a means of communication in the form of social media. which users can quickly access.

Medan State University is one of the state universities in North Sumatra Province, of course with the existence of Medan State University as an educational facility in North Sumatra which has a large student population. Based on data on the number of students in the 2019/2020 period, there were 26168 students and 952 educators or lecturers. [4]. With the number of students and lecturers, it is certainly not easy to provide information and build and maintain the image of the institution in front of the public. The image of an institution or organization is how the public views the organization, of course related to the perceptions and interpretations that appear in the heads of the audience or recipients of the message to the identity of the organization. The image of an organization is outside-in or something that is seen or interpreted by the public towards an institution. Therefore, organizations or institutions cannot determine the image of their own institutions because they cannot control how their communications are received, interpreted, and understood by the public. What they do is research and analyze how the public perceives the institution and can create more effective communication strategies to influence the image of the institution in the eyes of the public [5].

One of the more effective communication strategies to influence the image of the institution, especially Medan State University, is to use communication through social media, one of which is Instagram. Medan State University has an Instagram @unimedofficial social media account which provides information to the public of all forms of activities carried out by Medan State University. Instagram users who follow the @unimedofficial Instagram account certainly have their own perceptions of the image of Medan State University by seeing the post from @unimedofficial. 
Based on the above background, the researcher is interested in conducting research with the title "Student Perception of the Image of Medan State University through Instagram Social Media@UnimedOfficial".

Based on the background described above, we obtained problem formulation as follows (1) how do students perceive the image of Medan State University through social media Instagram? (2)what is the student's perception about @unimed.official Instagram content? Based on the formulation of the problem above, the research objectives are as follows: (1) to find out students' perceptions of the image of Medan State University through Instagram social media (2) to find out student perceptions of @ unimedofficial Instagram contents. The outputs of this research consist of mandatory outcomes, Reputable International Publications in proceedings at scopus indexed scientific seminars or Web of Science (Submit/Accepted/Published). Copyright (Certificate) of Research Report Additional: Teaching materials or parts of Textbooks that can be used for students (Drafts/ISBN). The research contributions are as follows: a. Knowledge development in the field of administration and communication in the scope of office management, b. Adding input to Medan State University regarding institutional governance,c. As input for the use and development of technology, especially the use of social media.

\section{Theory}

\subsection{Perception}

Etymologically, perception or in English perception comes from the Latin perception, from percipere, which receives or takes. Perception is the experience of objects, events, or relationships obtained by inferring information and interpreting messages. Perception is a process of sensory cues (sensory) and relevant past experiences organized to give us a structured and meaningful picture of a particular situation. [6].

Perception is observations about objects, events or relationships obtained by inferring information and interpreting messages. [7] Perception is a process related to the entry of messages or information into the human brain, through human perception continuously in contact with the environment. [8]. Perception is defined as the process of understanding or giving meaning to an information on a stimulus. Stimulus is obtained from the process of sensing objects, events or relationships between symptoms, which are then processed by the brain. The process of cognition starts from perception [9].

Most of the principles of perception based on gestalt theory are that perception is not the sum of the parts that a person perceives, but rather, is the whole. Gestalt theory lays out several principles that can explain how a person organizes sensations into a form of perception. The main perception principle is the figure and ground principle. This principle illustrates that humans, intentionally or not choose a series of stimuli that become the main focus or form. To perceive a stimulus that becomes a figure and a stimulus that is left as a ground, there are several organizing principles, which are as follows; The principle of proximity, a person tends to perceive stimuli that are close to one group. The principle of similarity, someone tends to perceive the same as a unit. The principle of continuity, this principle shows that the work of the human brain naturally performs the process of completing the information received even though the stimulus is not actually equipped. In addition to technical factors, such as the clarity of the stimulus (clear sound, clear image), the richness of 
the stimulus source (media such as audio-visual), perception is also influenced by psychological factors. This psychological factor even determines how to perceive information/messages/stimulus. The most dominant factor is the expectancy factor of the recipient of the information. This expectancy provides a certain frame of mind (mental set) that prepares a person to perceive in a certain way. This frame of mind is influenced by the following: Availability of previous information, the absence of information when a person receives a new stimulus for himself will cause confusion in perceiving. Needs, a person tends to perceive something based on current needs. Past experience, as a result of the learning process, experience greatly influences the way a person perceives something.

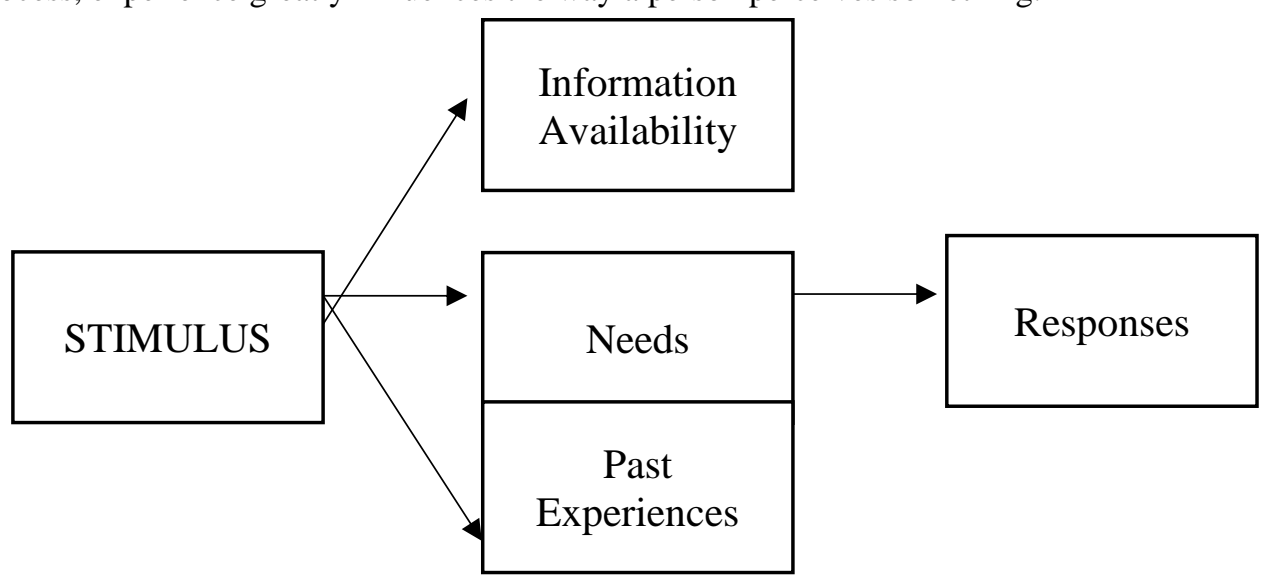

Fig. 1. Determination of perceptions [8].

\subsection{Organizational Image}

Organizational image is defined as a global assessment consisting of a set of beliefs and feelings that everyone has about an organization. The purpose of the image of the organization or company is so that the company can be understood clearly and accurately. It relates to emotions so that the image of the organization is seen differently from one person to another. Company image consists of four key elements where the image can affect employees, target group community. The four elements are as follows:

a. Thoughts about the organization or company.

b. Recognition of the organization.

c. Reputation.

d. Comparison of the organization with its competitors.

The creation of an organization's external image consists of seven main factors, namely as follows: 1. Customer satisfaction, 2. Product quality, 3. Real/tangible image, 4. Advertising, 5. Sponsorship 6. Media relations and 7. Social responsibility [5].

The types of images are as follows:

a. Shadow image (Mirror Image) is the image attached to people or members of the organization, and the image held by insiders recognizes the outside view of the organization. The shadow image is almost always inaccurate, or not in accordance with the actual reality.

b. Current image. It is the opposite of the shadow image or view held by outsiders about an organization. 
c. The desired image (Wish Image) Is an image desired by the management. This image is also not the same as the actual image. Usually the expected image is better or more pleasant than the existing image.

d. The image of the company or institution (Corporate image). Is the image of an organization as a whole. A business entity that has a positive corporate image is more expensive to sell its products or services.

e. Multiple images. The number of employees or individual branches or representatives of a company or organization or company as a whole.

The image variation should be kept to a minimum and the company's image should be upheld as a whole [10].

\subsection{Social Media}

One of the duties of public relations is to disseminate information and policies in accordance with their respective institutions/institutions to the public, accommodate and process the aspirations of the community, and accommodate public trust in order to maintain the image and reputation of the institution. . One of the efforts to provide such information is the use of social media, social media has formed and supported new ways of communicating, interacting and collaborating.

Social media, such as television, radio, and newspapers were popular information media before the 2000s. But now its popularity has been degraded by internet-based information media. Even though television seems irreplaceable, the portion of television media continues to shrink, and internet-based technology is a tool that will continue to be used for the foreseeable future [11].

From the explanation above, the definition of social media from the experts is as follows: According to Shirky, social media and social software are tools to increase the ability of users to share, cooperate (to-co-operate) among users and take collective action, all of which are outside the institutional and organizational framework. Boyd, describes social media as a collection of software that allows individuals and communities to gather, share, communicate, and in certain cases collaborate or play with each other. Social media has the power of usergenerated content (UGC) where content is generated by users, not by editors as in mass media institutions. According to Van Dijk, social media is a media platform that focuses on the existence of users who facilitate them in their activities and collaboration. Therefore, social media can be seen as a strengthening online medium (facilitator) [5].

The principles of social media are:1. Factual, namely information conveyed through social media based on clear data and facts taking into account the public interest. 2. Delivered through social media so that it can be accessed easily and known by anyone, anytime, anywhere in conveying messages correctly, honestly, and as is 3. Participation and engagement, namely the delivery of information through social media aimed at encouraging public participation and involvement by providing comments, responses, and input to agencies

The benefits of social media are as follows: 1. Disseminate government information to reach the public. 2 . build the role of state apparatus and society through social media 3 . socialize future development strategies and objectives. 4. build interaction between government and society. 5. increase public awareness and participation in government policies and programs. 6. explore the aspirations, opinions, and input of the community towards government policies and programs [12].

\subsection{Instagram}


Instagram was originally formed by the Burb INC company, the Burb INC company is a company that has a vision and mission in making applications for gadgets. at the beginning of the formation of the Burb INC company, the company only did a lot of making applications for gadgets. Instagram also started from programmers and at the same time its CEO, Mike Krieger and Kevin Systrom, they are both one or two of the most important people in the establishment of Instagram. If they don't exist, then Instagram doesn't exist. Instagram was founded with Burb INC in early 2010 around January. The word Instagram comes from a combination of two words, namely "insta" comes from the word "instant" like a polaroid camera which in ancient times was better known as "instant photos". While the word "gram" comes from the word "telegram" as it is known that the telegram can send information to anyone quickly. The two words above, namely "insta" and "gram" are combined into "Instagram". Instagram, which is present in this sophisticated era, utilizes the internet to send photos quickly, so in summary it can be concluded that the word "Instagram" is a combination of the words "insta" and "gram" [13].

The use of Instagram as a social media application created for use on smartphones. In addition, Instagram can be used to share photos/videos with followers, and also to anyone on Instagram. Instagram as a photo / video sharing application that makes it easy to share photos with friends has a feature before you upload the photo, namely editing photos / videos with various interesting effects and filters. Apart from being used as a social media application for sharing photos/videos, it is also used by business people to sell or promote their products and currently many government agencies have official Instagram accounts to build their image [14].

Since 2015 Medan State University has had social media accounts, one of which is Instagram with the name @unimedofficial which is managed by the public relations field. Instagram @unimedofficial has 55.8k followers, 35 followers and 1953 posts. Medan State University is one of the largest universities in North Sumatra which has students, lecturers, educators who are side by side with the development of technology and information connected to the internet. Instagram which is one of the social media within the Medan State University as a forum for providing academic information, activities, photos/videos, congratulations, cooperation agreements and other types of activities.

Students as Instagram users who follow Instagram @unimedofficial will of course see and judge what is uploaded to the Instagram account with what they see directly in real life, students will also be able to participate in monitoring and assessing the policies and activities of the State University Medan published through the Instagram account @ unimedofficial in the form of writing, photos, and videos.

To clarify the student's perception of the image of Medan State University through the Instagram@unimedofficial social media account, there are 2 aspects in interpreting the student's perception.

The Instagram profile is an identity created on the @ unimedofficial social media account which consists of an institutional statement on the identity, namely the presence of the Medan State University logo, Instagram manager in this case UNIMED public relations, website address:, UNIMED address, and telephone number. 


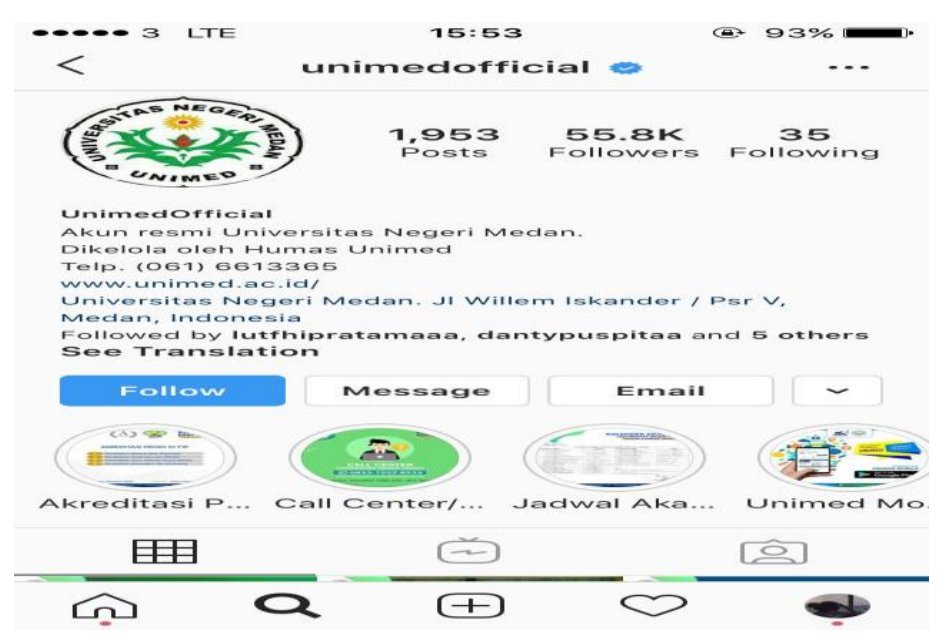

Fig. 2. Instagram profile.

Instagram content is part of academic information, student activities, congratulatory academic activities, institutional policies.

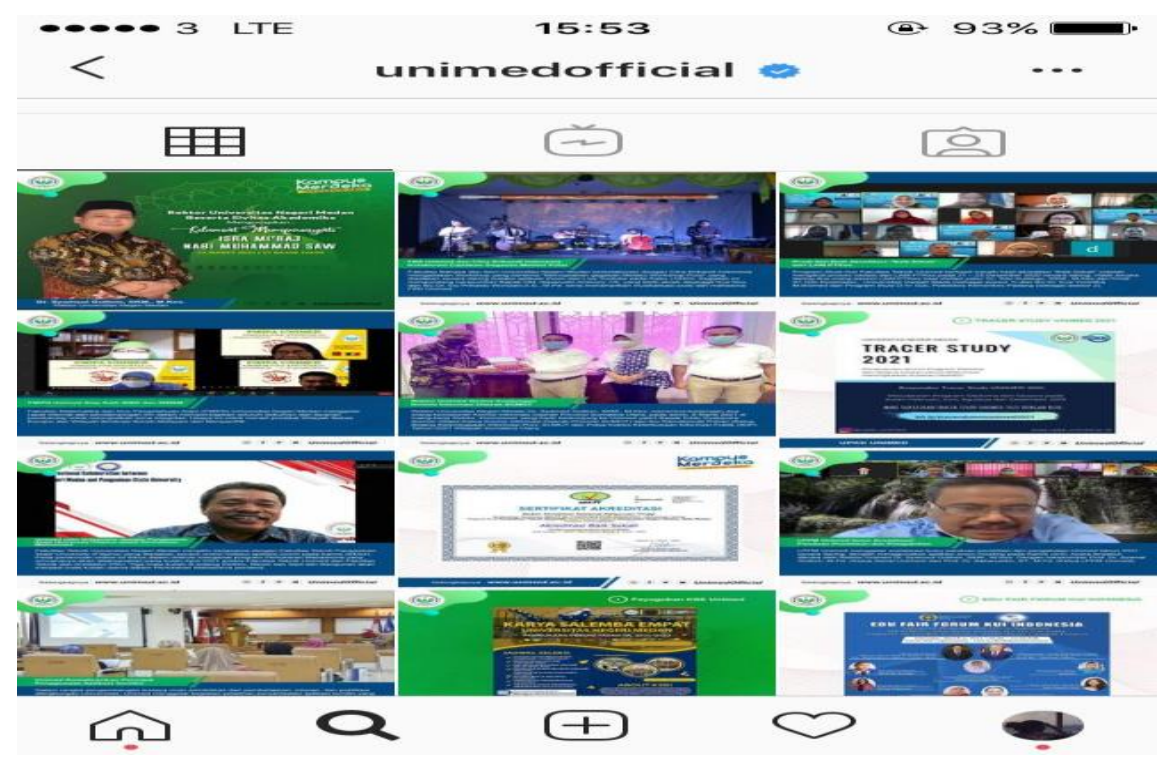

Fig. 3. Instagram content.

\subsection{Framework of Thinking}

The framework is made to simplify the research process because it includes the objectives of the research itself. This research was conducted to examine the image of the State University of Medan. In assessing the image of an institution, it is necessary to analyze 
through the perceptions of various parties. The main purpose of this study was to determine student perceptions of the image of Medan State University through Instagram social media accounts.

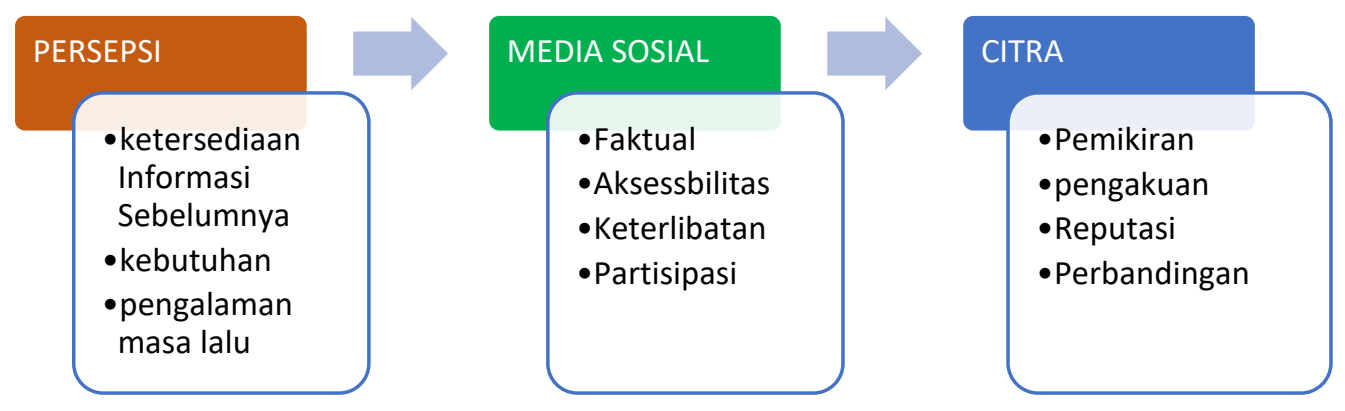

Fig. 4. Framework of Thingking.

\section{Method}

\subsection{Types of Research}

This type of research is a qualitative descriptive study, with the aim of knowing students' perceptions of the image of Medan State University through the @ unimedofficial Instagram account. Basically, qualitative research methods are intended for research that is observing cases. Judging from the object, the research that the author can do includes field research because the data needed to compile scientific papers are obtained from the field. This research uses a qualitative approach aimed at understanding social phenomena from the participant's point of view or perspective. Participants are people who are interviewed, observed, asked to provide data, opinions and thoughts and perceptions [15].

Qualitative research method is a research method based on the philosophy of postpositivism, used to examine the condition of a natural object, (as opposed to an experiment) where the researcher is the key instrument, the sampling of data sources is done purposively and snowball, the collection technique is triangulation (a combination of ), data analysis is inductive/qualitative, and qualitative research results emphasize meaning rather than generalization. [16].

\subsection{Population and Research Sample}

Definition of population, namely the totality of all possible values, the results of calculations or measurements, quantitative or qualitative about certain characteristics of all members of a complete and clear set that you want to study. [17] The population in this study were all students of the Office Administration Study Program, Faculty of Economics, State University of Medan. The sample is part of the individual who can be considered to have and reflect the state of the population or as a representative of the population studied by Arikunto, S [18]. The samples in this study were students of semester VII (Seven) classes A and B in the Office Administration Education Study Program, Faculty of Economics, State University of Medan. 


\subsection{Research Location and Time}

This research is located in the Office Administration Education Study Program, Faculty of Economics, Medan State University during May 2021 to December 2021.

\subsection{Data collection technique}

Interviews are a good tool to bring research topics to life, they are also a great method of collecting data on contemporary subjects that have not been studied extensively and there is not much literature on them. Interviews can be conducted face-to-face and also by telephone, face-to-face interviews are conducted personally between the researcher and the respondent. Meanwhile, the telephone interview is a conversation between the interviewing researcher and the interviewee. According to Yaniawati I [19], interviews are divided into four types of interviews, namely:

a. Open and in-depth interview. Digging as complete data as possible as deep as possible so that the researcher's understanding of the existing phenomena is in accordance with the understanding of the actors themselves.

b. Closed and Structured Interview. Interviews were conducted with one resource person.

c. Group interview. Reveal data and its meaning from a group of people based on the results of interviews that are focused or directed at a problem under study.

d. Telephone interview. Assist researchers in making it easier to collect data if it is not possible to visit sources one by one.

e. Interview by E-mail. Indirect interviews. With the formulation taken, the researcher used open and in-depth interviews in order to obtain relevant and clearer and more detailed data at the same time.

In an effort to obtain data and information in the form of written notes/images stored related to the problem under study. Documents are facts and data stored in various materials in the form of documentation. Most of the available data is in the form of documentation.

\subsection{Informant Determination Technique}

Informants are the main sources of information in this study other than sources of secondary data. is a person who is used as a source of information for interviews. Determination of informants is done by taking key informants with purposive techniques or techniques for determining informants based on certain considerations, usually related to the scale of involvement, knowledge, and authority of a person with the object of research. The informants determined in this study are students. Students are part of the Medan State University. Determination of informants is also very dependent on the dynamics of conducting research in the field, so it is possible if in carrying out the research there are people outside those specified above, but have information related to the data needed, then that person will be used as a research informant.

\subsection{Data Analysis Technique}

The data analysis technique that will be used in this study is the interactive model of Miles and Huberman. The following is a chart and explanation of Miles and Huberman's interactive model [15]. 


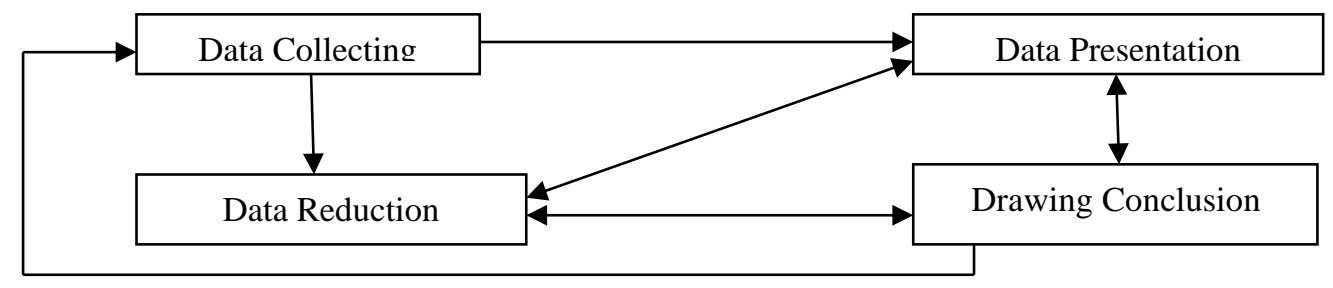

Fig. 5. Technical analysis data flowchart [15].

Data Collection is an effort to collect data in this study using interview techniques and document collection by paying attention to triangulation techniques. Data reduction means summarizing, choosing the main things, focusing on the important things, looking for themes and patterns. Thus the data that has been reduced will provide a clearer picture and make it easier for researchers to conduct further data collection. Data Presentation in qualitative research can be done in the form of brief descriptions, charts, relationships between categories. By displaying the data, it will be easier to understand what is happening, plan the next work based on what is understood. The next stage is drawing conclusions and verification. The initial conclusions put forward are still temporary, and will change if no strong and supporting evidence is found at the next stage of data collection. However, if the conclusions put forward at the initial stage are supported by valid and consistent evidence when the researchers return to the field to collect data, then the conclusions put forward are credible conclusions.

\subsection{Data Credibility Test Techniques}

In qualitative research, the credibility of the data obtained is a very important aspect. For this reason, it is necessary to test the credibility of the data, in this study the triangulation technique was used. Wiersma, as quoted by Sugiyono [15] explains that "triangulation is qualitative cross-validation. It assesses the sufficiency of the data according to the convergence of multiple data sources or multiple data collection procedures". Through this definition, it can be understood that triangulation is a credibility test technique in which a series of cross-tests are carried out from various data sources, various data collection techniques and across time.

\section{Result}

There are two discussions in this study, namely how students' perceptions of Medan State University through social media Instagram. Second, how are students' perceptions of accounts or uploads from the unimed@official Instagram social media account. With these two discussions, it is important to explore more deeply how students perceive the two things discussed.

The triangulation process can be carried out until finally getting the results of the triangulation test. The triangulation technique used in collecting data by interview using triangulation techniques and triangulation of sources. This process is carried out in order to 
produce information that has a high level of credibility and can describe information that actually occurs in the interaction space. Triangulation techniques consist of observation, interviews and documentation. The process carried out by researchers is by visiting the research site, observing the actors in the study, and being in the interaction room to find out the activities carried out. The following are the results of interviews from respondents as follows:

Table 1. Interview Results from Respondents 2021 of "What do you think about the existence of the @ unimedofficial Instagram account owned by UNIMED?"

\begin{tabular}{|l|l|}
\hline Informan & Hasil Wawancara \\
\hline Icha Tri Cahyani Damanik & $\begin{array}{l}\text { Official unimed account makes it easy for students to find } \\
\text { out the latest information about campus }\end{array}$ \\
\hline Rika Aida Hanum & $\begin{array}{l}\text { The existence of the @unimedofficial account in my } \\
\text { opinion is very good because the account is an information } \\
\text { delivery that makes it easier for students to know } \\
\text { everything about UNIMED info }\end{array}$ \\
\hline Naomy Oktavia Siahaan & $\begin{array}{l}\text { In my opinion, the official UNIMED Instagram account } \\
\text { can make it easier for students to find out the latest } \\
\text { information related to campus activities. }\end{array}$ \\
\hline Amzon Niagara Silaban & $\begin{array}{l}\text { The existence of the @unimedofficial instagram account } \\
\text { helps me and students in finding information. }\end{array}$ \\
\hline
\end{tabular}

Based on the results of the interviews in the table above, it can be seen that the existence of the unimed@official Instagram account is very helpful for students in finding information related to activities and all activities from Medan State University. With the social media Instagram, students are faster in accessing information both academically and student information and other forms of activities on campus. From the explanation above, it can be conceptualized that social media is a necessity in today's digital era. Access to information is getting faster and more accurate.

Table 2. Interview Results from Respondents 2021 of "W hat do you think about posts or uploads related to routines or activities from Medan State University? ”

\begin{tabular}{|l|l|}
\hline Informan & Hasil Wawancara \\
\hline Mia Aprilia & $\begin{array}{l}\text { Posts related to UNIMED routines are quite good and can } \\
\text { be used as references about UNIMED }\end{array}$ \\
\hline Windi Astika & I can find out what educational activities unimed does \\
\hline Muhammad Rizki Nasution & $\begin{array}{l}\text { The posts are very interesting, there are many posts about } \\
\text { achievements and activities carried out so that they become } \\
\text { one of the motivations for students }\end{array}$ \\
\hline Kharisma Paramita & $\begin{array}{l}\text { One of the academic information on UNIMED's official } \\
\text { Instagram account is the academic calendar. I think this } \\
\text { information is very important for every student. }\end{array}$ \\
\hline
\end{tabular}

Based on the results of the interviews in the table above, it can be seen that students' opinions regarding posts and uploads related to routines and activities related to Medan State University received responses that uploads and posts are interesting things and as information material for academic and student activities and as educational material. for students to 
develop knowledge and science. Likewise with the motivation for students related to posting a series of achievements from students and lecturers.

Table 3. Interview Results from Respondents 2021 of " What do you think about academic information posted or uploaded from the @unimedofficial Instagram account?"

\begin{tabular}{|l|l|}
\hline Informan & Hasil Wawancara \\
\hline Icha & $\begin{array}{l}\text { It's very useful for me, where the information which I get } \\
\text { can be as guidance in carrying out various academic affairs } \\
\text { on campus }\end{array}$ \\
\hline Ulfa Khairunnisa & $\begin{array}{l}\text { Very good, so that students know UNIMED academic } \\
\text { information and make students more enthusiastic to } \\
\text { achieve brilliant achievements. Not only for the UNIMED } \\
\text { community, but also for the outside community so that } \\
\text { they know how academically UNIMED or its students } \\
\text { have achieved. }\end{array}$ \\
\hline Romana Angel & Provide up-to-date and objective information \\
\hline Rika Purnamasari & $\begin{array}{l}\text { Can help students to find out the latest information } \\
\text { uploaded by Medan State University }\end{array}$ \\
\hline
\end{tabular}

Based on the results of the interviews in the table above, it can be seen that the average respondent answered that Instagram managed by UNIMED was very helpful for students in finding and updating academic information to help lecture activities ranging from paying tuition fees, filling out KRS, KHS, graduation, and other academic schedules. has been set by UNIMED.

Table 4. Interview Results from Respondents 2021 of " What do you think regarding the information on student activities uploaded to the @unimedofficial Instagram account?"

\begin{tabular}{|l|l|}
\hline Informan & Hasil Wawancara \\
\hline Mardiah Irwanda Gultom & $\begin{array}{l}\text { Its information is very useful for students to open their } \\
\text { minds and give new insight }\end{array}$ \\
\hline Mia Aprilia & $\begin{array}{l}\text { Posts about student activities is positive dan should } \\
\text { maintaned. }\end{array}$ \\
\hline Erika & $\begin{array}{l}\text { Is good, for the posts about students' activities could } \\
\text { attract student' attention to joint student activities in } \\
\text { UNIMED }\end{array}$ \\
\hline Reynel Sisda Wa & $\begin{array}{l}\text { Give strength and motivation for students to participate } \\
\text { in student activities }\end{array}$ \\
\hline
\end{tabular}

Based on the results of interviews from several respondents, it can be seen that information on student activities is very useful, based on the results of interviews that the information can open up thoughts and add scientific insight and the scope of student organizations in supporting student character development, the information on student activities motivates students to participate in activities students in UNIMED.

Table 5. Interview Results from Respondents 2021 of "What do you think about the post related to the national holiday congratulation made by UNIMED on the Instagram account @ unimedofficial?" 


\begin{tabular}{|l|l|}
\hline Informan & Hasil Wawancara \\
\hline Icha & $\begin{array}{l}\text { It indicated that UNIMED has high nationality values, } \\
\text { and it help to build student consciousness. }\end{array}$ \\
\hline Ananda & $\begin{array}{l}\text { It showed that UNIMED actively participating in } \\
\text { national holiday. }\end{array}$ \\
\hline Sisda & $\begin{array}{l}\text { It's positive, and it useful as reminder for students dan } \\
\text { society to celebrate national holiday, and to build spirit } \\
\text { of tolerance. }\end{array}$ \\
\hline Rani & $\begin{array}{l}\text { It's very good, for it remind us to remember historical } \\
\text { events which happened to attain our independence } \\
\text { status. }\end{array}$ \\
\hline
\end{tabular}

From the results of the interviews in the table above, it can be seen that students' opinions regarding the posting of congratulatory national holidays made by the UNIMED Instagram account received a positive response, among the informants explaining that the post indicated that all UNIMED residents had a high sense of nationality and nationality, especially considering the events history of independence and other history related to national holidays.

Table 6. Interview Results from Respondents 2021 of "What do you think about the photos uploaded or in the instastory on the Instagram @ unimedofficial social media account?"

\begin{tabular}{|l|l|}
\hline Informan & Hasil Wawancara \\
\hline Rizky Siregar & $\begin{array}{l}\text { It's very good, for it gave us informative fotos } \\
\text { about UNIMED, and it can be useful to introduce } \\
\text { UNIMED as an institution with good image. }\end{array}$ \\
\hline Ulfa & It's good, and very informative. \\
\hline Cindy & $\begin{array}{l}\text { It helpful enough to give the students latest } \\
\text { informations. }\end{array}$ \\
\hline Pitra Ade & $\begin{array}{l}\text { It informative enough; not only helpful through } \\
\text { its posts, but also through instatory. }\end{array}$ \\
\hline
\end{tabular}

From the results of interviews with informants in the table it can be explained that posts or uploads and instastory in the form of photos are on the UNIMED Instagram account, the respondents gave the opinion that the photo is very attractive to students, not only in terms of utilization of information and others but the design is very interesting as a medium. information as well as timely posting of any kind of activity or information.

Table 7. Interview Results from Respondents 2021 of "What do you think about the uploaded video or instastory on Instagram @ unimedofficial social media account?"

\begin{tabular}{|l|l|}
\hline Informan & Hasil Wawancara \\
\hline Cristin & $\begin{array}{l}\text { Very good, for it becomes informative media which } \\
\text { share videos about UNIMED, and it could be useful to } \\
\text { promote and introduce UNIMED as an institution with } \\
\text { good image }\end{array}$ \\
\hline Indah Sari & $\begin{array}{l}\text { It's Good. But actually there are many good video about } \\
\text { students activities which escapes the admin to post. }\end{array}$ \\
\hline
\end{tabular}




\begin{tabular}{|l|l|}
\hline Naomy & $\begin{array}{l}\text { Similar to photo posts, uploaded video posts must also } \\
\text { have information value that is very, very useful for } \\
\text { every element at UNIMED. }\end{array}$ \\
\hline Greace & $\begin{array}{l}\text { It's good, because the video can build student } \\
\text { enthusiasm and motivation and can build positive things } \\
\text { for students }\end{array}$ \\
\hline
\end{tabular}

From the results of the interviews from the informants in the table above, the results of the interviews related to student opinions regarding video uploads on Instagram UNIMED received a very good response, it can be seen from students' opinions that video uploads are a medium of information in promoting UNIMED to be known more in the eyes of the public, as well as videos related to student activities that express academic and non-academic achievements to build the spirit of student motivation to be more active in improving academic achievement and other achievements.

Table 8. Interview Results from Respondents 2021 of "What do you think about the academic community or functionaries who often appear on Instagram accounts that are uploaded or in stories on social media accounts?"

\begin{tabular}{|l|l|}
\hline Informan & Hasil Wawancara \\
\hline Indah & $\begin{array}{l}\text { This will help students to get to know the figures of the } \\
\text { academic community and functionaries at UNIMED }\end{array}$ \\
\hline Rizky & $\begin{array}{l}\text { What is often uploaded is not only campus officials, but } \\
\text { academics or campus functionaries who have achievements } \\
\text { or become resource persons in student activities also appear. }\end{array}$ \\
\hline Sri ratu & $\begin{array}{l}\text { It's very good, because Unimed can introduce internal parties } \\
\text { within the UNIMED community both to new students, } \\
\text { students, and parties who want to get to know the UNIMED } \\
\text { community so that at any time they can say hello }\end{array}$ \\
\hline Dian Ranti & $\begin{array}{l}\text { Can be increased again as a form of appreciation for students } \\
\text { and lecturers to improve achievement }\end{array}$ \\
\hline
\end{tabular}

Based on the results of the interviews in the table above, it can be explained that students' opinions regarding the emergence of functionaries or the academic community from every activity at UNIMED gave a very good response, this can be seen from several excerpts from interviews from informants who said that these appearances could be more personally acquainted with functionaries at the university and faculty level, the informant also said that the appearance was part of the motivation for students because some functionaries often filled activities as resource persons in scientific meeting activities.

Table 9. Interview Results from Respondents 2021 of "What do you think about the results of the activities of the Tri Dharma College lecturers and achievement lecturers who are uploaded or have stories on social media accounts?"

\begin{tabular}{|l|l|}
\hline Informan & Hasil Wawancara \\
\hline Cindy & $\begin{array}{l}\text { Of course, I'm proud if Unimed posts the achievements on } \\
\text { our campus. Proving that Unimed also has many } \\
\text { achievements }\end{array}$ \\
\hline Mei & It is very inspiring for students to be more enthusiastic in \\
\hline
\end{tabular}




\begin{tabular}{|l|l|}
\hline & $\begin{array}{l}\text { learning, especially by seeing the achievements of our } \\
\text { lecturers, seeing the quality of the lecturers }\end{array}$ \\
\hline Ananda & $\begin{array}{l}\text { It's very good because this post provides information to the } \\
\text { public regarding these achievements through the UNIMED } \\
\text { Instagram account. }\end{array}$ \\
\hline Grace & $\begin{array}{l}\text { It is very good, because the results of these activities are } \\
\text { not only as an illustration, but as a reference for students } \\
\text { and the entire Unimed environment in building enthusiasm } \\
\text { and motivation which will later become the next target for } \\
\text { UNIMED. }\end{array}$ \\
\hline
\end{tabular}

From the results of interviews with informants from the table above, an explanation regarding student opinions regarding the results of lecturer activities in the form of college tri dharma and lecturers who have achievements posted on Instagram social media accounts UNIMED argues that through this social media account proves that the activities of lecturers In carrying out the tridharma of higher education and lecturers having achievements can be seen by UNIMED residents and the community, then the informants also argue that through posting the achievements of lecturers they see the quality of UNIMED lecturers and as a motivation for students' enthusiasm for learning in exploring the knowledge gained from the lecturer.

Table 10. Interview Results from Respondents 2021 of "After you follow and observe the Instagram@ unimedofficial social media account, what do you think about UNIMED on Instagram social media accounts?"

\begin{tabular}{|l|l|}
\hline Informan & Hasil Wawancara \\
\hline Ratu & $\begin{array}{l}\text { In my opinion the @unimedofficial Instagram account is } \\
\text { very informative and with this account it helps students } \\
\text { in getting information related to activities from Unimed, } \\
\text { especially now that learning is done online. So, in my } \\
\text { opinion, this account can be used as a medium to convey } \\
\text { information online. }\end{array}$ \\
\hline Ananda & $\begin{array}{l}\text { In my opinion, the UNIMED Instagram account is good } \\
\text { which is always a medium of information about any } \\
\text { positive things related to UNIMED, both activities and } \\
\text { achievements at UNIMED. }\end{array}$ \\
\hline Nisa & $\begin{array}{l}\text { In my opinion, UNIMED is a campus that is quite active } \\
\text { in various activities, both academic and non-academic, } \\
\text { why do I say that because with postings that often post } \\
\text { about the achievements and activities of UNIMED and its } \\
\text { students. }\end{array}$ \\
\hline Mei & $\begin{array}{l}\text { Seeing from the posts on the Instagram account, my } \\
\text { opinion is that universities do a lot of educational } \\
\text { activities that are useful for many people. }\end{array}$ \\
\hline
\end{tabular}

Based on the results of the interviews in the table above, it can be explained that students' opinions about UNIMED through Instagram media accounts give the opinion that UNIMED as one of the best universities in North Sumatra must show the public that UNIMED has certain advantages or achievements that must be shown to unimed residents and society in general, because with this social media people want to know how the activities of the continuity of the learning process as well as student activities and lecturers who have achievements at the national and international levels. 
Based on the results of the interviews in the tables above, it can be seen that the image of UNIMED is good, based on the responses or results of interviews from respondents or students. The creation of an organizational image consists of seven main factors, namely as follows: 1. Customer satisfaction, 2. Product quality, 3. Real/tangible image, 4. Advertising, 5. Sponsorship 6. Media relations and 7. Social responsibility [5].

In this case, the perception of students regarding social media Instagram @unimedofficial makes students satisfied and feels UNIMED guarantees services, especially in the academic field and student activities as well as other information related to activities within the UNIMED environment. In terms of providing information in public on UNIMED's Instagram, according to some students, it has been very helpful in absorbing information. Each user can easily access content, write opinions, and reply to each other's comments. Meadows-Klue (2007) states that content in social media can easily move from one user to another, due to social media applications and technologies that have no boundaries. This convenience encourages students to produce content, messages or information through social media, so that the information and content produced can be accessed by everyone. Publicity activities that are often carried out by public relations at the university are a form of communication application that aims to convey messages to UNIMED residents with the intention of providing understanding and disseminating information, so that they can change perceptions and attitudes towards information or policies that are disseminated. The development of information and communication technology places these communication activities increasingly important. This progress has resulted in a shift in conventional media to the new media era which requires agencies to wisely utilize the presence of new media as a new forum for public information (Ardianto, 2011: 273).

\section{Conclusion}

Based on the analyzed data, the following conclusions were obtained that students' perceptions of the image of Medan State University through social media Instagram (a) unimedofficial received good responses, this was seen from the results of interviews with students, the amount of academic and student information that was really needed by students seen from uploads or posts from social media Instagram @unimedofficial. Students' perceptions of the image of Medan State University through lecturer activities or the frequent appearance of official or functionary activities at the University and Faculty level on social media@unimedofficial received a good response, this was seen from the answers from respondents who stated that by posting these activities they could get to know lecturers or officials at the University and Faculty level, as well as motivation for students related to the achievements of lecturers in the UNIMED environment. Student perceptions related to uploads on Instagram@unimedofficial social media when viewed from the responses of respondents who stated that the upload was very useful when viewed from photo and video uploads in each activity, interest in seeing photos or videos from the upload based on attractive photo designs and video editing. The need for increased posting of all activities that take place within UNIMED through the @unimedofficial Instagram media account in order to absorb information to students and the public.

The need to socialize the existence of social media Instagram@unimedofficial to students and lecturers or alumni as a form of efficiency of accurate information barns to UNIMED residents, communities and alumni. 


\section{References}

[1] Ryvo A, Julianto AN, Abdurrachim A, Amien AA, Prakoso DS, Affian D, Wulandari ERP, Maulana FVA, Sungkono FP, Ardipraditiya FH. Peradaban Media Sosial di Era Industri 4.0. Prodi Ilmu Komunikasi Universitas Muhammadiyah. Malang: 2020; 9.

[2] https://tekno.kompas.com/read/2021/02/23/16100057/jumlah-pengguna-internet-indonesia-2021tembus-202-juta

[3] Nasrullah R. Media Sosial: Perspektif Komunikasi, Budaya, dan Sosioteknologi. Bandung: Simbiosa Rekatama Media; 2015.

[4] https://pddikti.kemdikbud.go.id/search/universitas\%20negeri\%20medan

[5] Suwatno H. Pengantar Public Relations Kontemporer. Bandung: PT Remaja Rosdakarya; 2018.

[6] Liliweri A. Komunikasi Antar Personal. Prenada Media; 2017.

[7] Rakhmat, Jalaludin. Psikologi Komunikasi. Bandung: PT. Remaja Rosdakarya; 2012.

[8] Slameto. Belajar dan Faktor-Faktor yang Mempengaruhinya. Jakarta: Rineka Cipta; 2010.

[9] Kadar N, Khaerul, U. Komunikasi Public Relations. Bandung, CV Pustaka Setia; 2012.

[10] Yogatama A, Sos S, Vidyarini TN., Sos, S, Comms M, Monica V, \& Sos S. Public Relations: Sebuah Pengantar. Penerbit Qiara Media; 2021.

[11] Sulianta F. Keajaiban Sosial Media. Elex Media Komputindo; 2015.

[12] Peraturan Menteri Pendayagunaan Aparatur Negara Dan Reformasi Birokrasi Republik Indonesia Nomor 83 Tahun 2012 Tentang Pedoman Pemanfaatan Media Sosial Instansi Pemerintah

[13] https://id.wikipedia.org/wiki/Instagram

[14] https://wearesocial.com/digital-2020

[15] Nana, S. S. 2010. Metode Penelitian Pendidikan. Bandung: Remaja Rosdakarya

[16] Sugiyono P. Metodologi Penelitian Kuantitatif Kualitatif dan R\&D. Bandung: Alpabet; 2011.

[17] Sudjana N, Ibrahim MA. Penilaian dan Penelitian Pendidikan. Bandung: Sinar Baru Algensindo; 2012.

[18] Arikunto S. Metode Penelitian Kualitatif. Jakarta: Bumi Aksara; 2006.

[19] Yaniawati I. Metode Penelitian Kuantitatif, Kualitatif, dan Campuran untuk Manajemen, Pembangunan, dan Pendidikan. Bandung: PT Refika Aditama; 2017. 